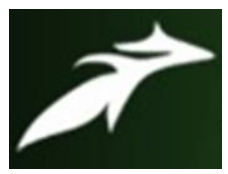

OYETORO John Oyewole et al, International Journal of Advances in Agricultural Science and Technology,

Vol.8 Issue.1, January-2021, pg. 66-74

ISSN: 2348-1358

Impact Factor: 6.057

NAAS Rating: 3.77

\title{
Utilization of Technology in Good Agricultural Practices (GAP) among Fruit and Vegetable Farmers in Osun State Nigeria
}

\author{
*OYETORO John Oyewole; **AKINTARO O.S; *AKINBOYE O.A; *ADEWOLE W.A \\ *Department of Agricultural Extension and Rural Development \\ Ladoke Akintola University of Technology, Ogbomoso, Nigeria \\ jooyetoro@lautech.edu.ng \\ **Teaching and Research Farm \\ Ladoke Akintola University of Technology, Ogbomoso, Nigeria
}

DOI: 10.47856/ijaast.2021.v08i1.009

\begin{abstract}
The study focused on utilization of technologies in Good Agricultural Practices (GAP) among fruit and vegetable farmers in Osun State. A structured interview schedule was administered to a total of 270 respondents using multi stage sampling technique. The GAP technologies identified on the utilization increasing ranking order include: timely harvest of fruits and vegetables (WMS=3.00), looking for varieties which are pest and disease resistant (WMS=2.97) and do not use empty fertilizer bags for carrying fruits and vegetables (WMS=2.93) ranked third. The least GAP utilized was avoiding use of refuse dumping site for cropping (WMS=0.43) which ranked last. The major constraints faced by the fruit and vegetable farmers in the area were high cost of cropping technologies (WMS=1.88), lack of credit facilities (WMS=1.81), and inadequate training for GAP (WMS=1.61). Pearson analysis shows that there is significant relationship between selected socioeconomic characteristics such as academic qualification $(r=0.541, p=0.022)$ and the utilization level of technologies in GAP. The study recommended adequate training on GAP technologies should be provided by extension agency.

Keywords: Technology, Agricultural Technology, Good Agricultural Practices, Fruits, Vegetables, Fruits and Vegetable Farmers
\end{abstract}

\section{Introduction}

Agriculture serves as a valuable source of income, it makes a significant contribution in the quest for poverty reduction and represents the main source of livelihood for 1.4 billion smallholder farmers and their families who produce nearly $70 \%$ of all food consumed worldwide (Food and Agricultural Organization FAO, 2010; Lowder et al. 2014; Onyekwelu et al. 2015). Worldwide, there are approximately 2.5 billion people involved in full-or part-time smallholder agriculture, managing an estimated 500 million small farms (International Fund for Agricultural Development IFAD, 2013). The agriculture sector is also the mainstay of the economies of most of the developing world. Furthermore in Sub-Saharan Africa an estimated $75 \%$ of resource-poor people rely on agriculture for their livelihoods, the sector employs about $60 \%$ of the workforce and contributes an average of $30 \%$ to Gross Domestic Product (GDP) (Chowa et al. 2013). It is 


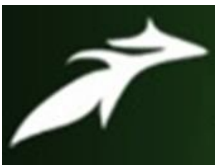

OYETORO John Oyewole et al, International Journal of Advances in Agricultural Science and Technology, Vol.8 Issue.1, January-2021, pg. 66-74

ISSN: 2348-1358

Impact Factor: 6.057

NAAS Rating: 3.77

estimated that nearly $70 \%$ of the people in developing countries live in rural areas where agriculture is the main source of livelihood, and there are some 36million smallholder farmers across the continent of Africa (Kalungu et al. 2013; Wright et al. 2014).

In Nigeria, agriculture contributes about $42 \%$ to the GDP, employs $70 \%$ of the active population (Osebeyo and Aye 2014). Smallholder farmers are the backbone of agricultural production in Nigeria with over $90 \%$ of the agricultural output is derived from resource-poor farming, carried out by smallholder farmers (<3hectres) who have been the principal source of the national food supply for many decades (Adedipe et al 2004). When considering food supply, fruits and vegetables occupy a pivotal role in nutrition requirements of human life.

Fruits and vegetables are considered in dietary guidance because of their high concentrations of dietary fiber, vitamins, minerals, especially electrolytes; and more recently phytochemicals, especially antioxidants (Slavin and Lloyd, 2012). Despite an increasing focus on the health benefits of fruits and vegetables, their consumption is below the recommended intake among adults (Schneider et al, 2007). Therefore, considering how nutritional related health problems have risen drastically globally, it seems critical that formal nutrition education aiming to increase knowledge of fruits and vegetables intake be given priority in health education programs and health promotion. Production of healthy fruits and vegetables requires certain agricultural practices otherwise termed as Good Agricultural Practices.

Good Agricultural Practices (GAPs) are collection of practices for on-farm production and postproduction processes, resulting in safe and healthy food and non-food agricultural products while taking into account economic, social and environmental sustainability (Food and Agricultural Organization FAO 2010; Lefebvre et al. 2015). GAPs cover a range of areas including maintaining soil fertility, water resource and irrigation management, cropland management, degraded land restoration, animal production and welfare, integrated pest management, integrated fertilizer management and conservation agriculture (Montagn et al. 2007). GAPs explicitly aim to increase the supply of safe and high-quality food by promoting more sustainable crop production (Ali, 2014) while also helping to improve market access and farmers' livelihoods (FAO, 2010). Although GAPs have the potential to play a significant role in improving agricultural practices, there is currently limited empirical evidence on the level of awareness and implementation of GAPs. Therefore, the paper examined utilization of technologies in good agricultural practices (gap) among fruit and vegetable farmers in Osun state, Nigeria. Specifically, it described the socio-economic characteristics of fruit and vegetable farmers, identified the technologies of GAP utilized by the fruit and vegetable farmers, and examined the constraints experienced by fruit and vegetable farmers towards utilizing GAPs technologies. 


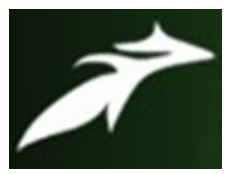

OYETORO John Oyewole et al, International Journal of Advances in Agricultural Science and Technology, Vol.8 Issue.1, January-2021, pg. 66-74

ISSN: 2348-1358

Impact Factor: 6.057

NAAS Rating: 3.77

\section{METHODOLOGY}

The study area is Osun State, Nigeria. Osun is an inland state in south-western Nigeria. Its capital is Osogbo. It is bounded in the north by Kwara State, in the east partly by Ekiti State and partly by Ondo State, in the south by Ogun State and in the west by Oyo State. Agriculture in the State of Osun is predominantly rain-fed with small-scale irrigation limited to Fadama farming. It is dominated by the peasantry and aged people cultivating less than one hectare. Agriculture employs over $70 \%$ of the labour force in the state (Osun State Government, 2018). The State was divided into three agro-ecological zones namely Iwo, Osogbo and Ife/Ijesa under the Osun State Agricultural Development Programme (OSSADEP). The list of registered fruit and vegetable farmers was obtained from Agricultural Development Programme (ADP) and All Farmers Association of Nigeria (AFAN) in Olorunda Local Government Area of Osun State. A multistage sampling technique was used to select 270 respondents from the study area.

The study contains both independent and dependent variables. The dependent variable of the study is the utilization of technologies in Good Agricultural Practices among fruit and vegetable farmers. This was measured by asking the respondents to list out the technologies involved in Good Agricultural Practices, and the frequency of utilizing each technology was scored on 4 points rating scale of: Always utilized $=3$, occasionally utilized $=2$, utilized before but discontinued $=1$, not utilized $=0$.

\section{Socioeconomic Characteristics of the Respondents}

Data presented in Table 1 shows that the mean age of respondents was 60 years. It was also revealed that most of the respondents $(61.1 \%)$ were married, $47.8 \%$ of the respondents were Muslims, and $68.8 \%$ of the respondents were males while $32.2 \%$ were females. This implies that both males and females were involved in utilizing technologies in Good Agricultural Practices. Also, the mean years spent in schooling was 7years. This implies that respondents had one form of education or the other which will assist them to understand the needs to utilize technologies in Good Agricultural Practices. Also, on the basis of primary occupation, 55.6\% of the respondents were farmers, $8.9 \%$ were civil servants. The mean household size being 9 persons, the mean annual income from vegetable and fruits production was $\mathrm{N}$ 695,078.00. This means that respondents earned considerable amount above poverty line from fruits and vegetable production. 


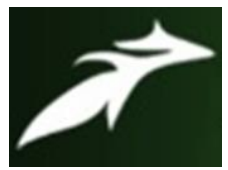

OYETORO John Oyewole et al, International Journal of Advances in Agricultural Science and Technology, Vol.8 Issue.1, January-2021, pg. 66-74

ISSN: 2348-1358

Impact Factor: 6.057

NAAS Rating: 3.77

Table 1: Distribution of respondents according to their socio-economic characteristics

$\mathrm{n}=\mathbf{2 7 0}$

\begin{tabular}{|c|c|c|c|c|}
\hline Socio-economic characteristics & frequency & percentage & mean & \\
\hline \multicolumn{5}{|l|}{ Age(Years) } \\
\hline$\leq 30$ & 9 & 3.3 & & \\
\hline $31-40$ & 27 & 10.0 & & \\
\hline $41-50$ & 30 & 11.1 & 60 & \\
\hline $51-60$ & 60 & 22.2 & & \\
\hline 61 and above & 144 & 53.4 & & \\
\hline \multicolumn{5}{|l|}{ Marital status } \\
\hline Single & 12 & 4.4 & & \\
\hline Married & 165 & 61.1 & & \\
\hline Separated & 30 & 11.1 & & \\
\hline Divorced & - & - & & \\
\hline Widow & 63 & 23.4 & & \\
\hline \multicolumn{5}{|l|}{ Religion } \\
\hline Islam & 129 & 47.8 & & \\
\hline Christianity & 114 & 42.2 & & \\
\hline Traditional & 27 & 10.0 & & \\
\hline \multicolumn{5}{|l|}{ Gender } \\
\hline Male & 183 & 167.8 & & \\
\hline Female & 87 & 32.2 & & \\
\hline \multicolumn{5}{|c|}{ Academic qualification (years spent in formal schooling) } \\
\hline No formal education & 105 & 38.9 & & \\
\hline$\leq 6$ years & 72 & 26.7 & & \\
\hline $7-12$ years & 51 & 18.9 & 7 & \\
\hline 13 years and above & 42 & 15.6 & & \\
\hline \multicolumn{5}{|l|}{ Primary occupation } \\
\hline Farming & 150 & 55.6 & & \\
\hline Civil servant & 24 & 8.9 & & \\
\hline Trading & 45 & 16.7 & & \\
\hline Transport services & 36 & 13.2 & & \\
\hline Others & 15 & 5.6 & & \\
\hline \multicolumn{5}{|l|}{ Household size (persons) } \\
\hline$\leq 5$ & 69 & 25.5 & & \\
\hline 6-10 & 141 & 52.3 & & 9 \\
\hline 11 and above & 60 & 22.2 & & \\
\hline
\end{tabular}




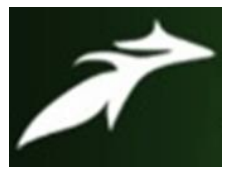

OYETORO John Oyewole et al, International Journal of Advances in Agricultural Science and Technology,

Vol.8 Issue.1, January-2021, pg. 66-74

ISSN: 2348-1358

Impact Factor: 6.057

NAAS Rating: 3.77

Annual income from fruits and vegetable production (Naira)

$\begin{array}{llrl}\leq 300,000 & 6 & 2.2 & \\ 301,000-600,000 & 105 & 38.9 & 695,078.00 \\ 601,000 \text { and above } & 159 & 58.9 & \end{array}$

\section{Source: Field Survey, 2019.}

Utilization of technologies in Good Agricultural Practices (GAP) by the respondents

Table 2 shows the distribution of respondents according to the utilization of technologies in Good Agricultural Practices (GAP). The technologies identified in their increasing ranking order include: timely harvest (WMS=3.00), looking for varieties which are pest and disease resistant (WMS=2.97) and do not use empty fertilizer bags for carrying vegetables (WMS=2.93) ranked third. The least GAP utilized was avoiding use of refuse dumping site for cropping (WMS=0.43) which ranked last. The findings imply that respondents utilized Good Agricultural Practices (GAP) technologies at different levels. Usage could be attributed to several factors such educational, cultural and economic realities. Utilization of GAP could lead to the production of safe and healthy fruits and vegetables which may command high price from selected markets such as supermarkets thereby boosting the income level of farmers.

Table 2: Distribution of respondents according to their utilization level of technologies in

\begin{tabular}{|c|c|c|c|c|c|c|}
\hline GAP Technologies* & $\begin{array}{l}\text { Always } \\
\text { utilized }\end{array}$ & $\begin{array}{l}\text { Occasionally } \\
\text { utilized }\end{array}$ & $\begin{array}{l}\text { Utilized but } \\
\text { discontinued }\end{array}$ & $\begin{array}{l}\text { Not } \\
\text { utilized }\end{array}$ & WMS & Rank \\
\hline \multicolumn{7}{|l|}{ Soil Management } \\
\hline $\begin{array}{l}\text { Cropping System (mixed } \\
\text { cropping) }\end{array}$ & $129(47.8)$ & $60(22.2)$ & $45(16.7)$ & $36(13.3)$ & 2.04 & 12 th \\
\hline Soil testing (indigenous) & $30(11.1)$ & $12(4.4)$ & $9(3.3)$ & $219(81.1)$ & 0.46 & 18 th \\
\hline \multirow{2}{*}{$\begin{array}{l}\text { Soil testing (modern) } \\
\text { Avoid use of refuse } \\
\text { dumping site for cropping }\end{array}$} & $42(15.6)$ & $12(4.4)$ & $15(5.6)$ & $201(74.4)$ & 0.61 & 17 th \\
\hline & $21(7.8)$ & $9(3.3)$ & $36(13.3)$ & $204(75.6)$ & 0.43 & 19th \\
\hline Liming acid soil & $48(17.8)$ & $30(11.1)$ & - & $192(71.1)$ & 0.76 & 15 th \\
\hline $\begin{array}{l}\text { Application of sulphur to } \\
\text { alkaline soil } \\
\text { Plant/ Seed identification }\end{array}$ & $48(17.8)$ & $30(11.1)$ & - & $\begin{array}{l}192 \\
(71.1)\end{array}$ & 0.76 & 15 th \\
\hline $\begin{array}{l}\text { Purchasing seed from tested } \\
\text { seller } \\
\text { Use optimal chemicals for }\end{array}$ & $258(95.6)$ & $3(1.1)$ & - & $9(3.3)$ & 2.89 & 6th \\
\hline seed preservation & $225(83.3)$ & $9(3.3)$ & - & $36(13.3)$ & 2.57 & 10th \\
\hline
\end{tabular}




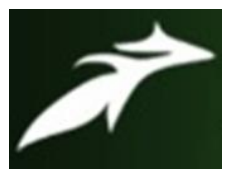

OYETORO John Oyewole et al, International Journal of Advances in Agricultural Science and Technology, Vol.8 Issue.1, January-2021, pg. 66-74

ISSN: 2348-1358

Impact Factor: 6.057

NAAS Rating: 3.77

Look for varieties which are

pest and disease resistant

$261(96.7)$

$9(3.3)$

$2.97 \quad 2$ nd

Keep seed in sealed container

$246(91.1) \quad 9(3.3)$

$15(5.6)$

2.89 th

Food Safety

Non infected animals faeces

used as manure for crops

$72(26.7) \quad 21(7.8)$

174

Timely harvest of crops

$270(100)$

(64.4)

0.97 14th

Use of adequate quantity of organic fertilizer

255 (94.4)

Record keeping

150 (55.6)

$57(21.1)$

$-$

Fertilizer use

Apply the required level of fertilizer at the right time

$252(93.3)$

$3(1.1)$

$15(5.6)$

8th

Use Organic fertilizer and well composted manure

$267(98.9)$

3(1.1) $2.97 \quad 2$ nd

Keep fertilizer in dry, clean and sheltered place

$255(94.4)$

$3(1.1)$

12(4.4)

$2.86 \quad 5$ th

Do not use empty fertilizer bags for carrying vegetables Pesticide Use

$264(97.8)$

$6(2.2)$

$2.934^{\text {th }}$

Only purchase and use registered pesticides

$231(81.1)$

$3(3.3)$

42(15.6)

2.5

10th

Do not apply pesticides during heavy rain

$141(52.2)$

$12(4.4)$

117(43.3) $1.66 \quad$ 13th

Adhere to the withholding period on the pesticide label Hold pesticides in original container

237(87.8)

$3(3.3)$

$24(8.9)$

$2.7 \quad 9^{\text {th }}$

Do not re-use pesticides

86(955.6) $3(1.1)$

$9(3.3)$

2.89

$6^{\text {th }}$

container for other usage

WMS = Weighted Mean Score

$6(2.2)$

2.93 4th

Source: Field Survey, 2019

* Multiple response

Constraints experienced by respondents towards utilization level of technologies in Good Agricultural Practices (GAP)

Table 3 shows the constraints experienced by the respondents towards utilization of technologies in Good Agricultural Practices. In the rank order of severity of the problems, high cost of cropping technologies was ranked first with weighted mean score (WMS) of 1.88.This was 


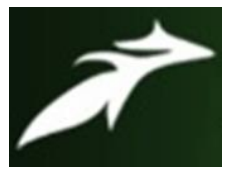

OYETORO John Oyewole et al, International Journal of Advances in Agricultural Science and Technology, Vol.8 Issue.1, January-2021, pg. 66-74

ISSN: 2348-1358

Impact Factor: 6.057

NAAS Rating: 3.77

closely followed by lack of credit facilities (WMS $=1.81$ ) which ranked second, training needed (WMS=1.61) which ranked third, lack of awareness about technologies (WMS=1.48) which ranked fourth, poor understanding of Good Agricultural Practices (WMS=1.29) which ranked fifth and farm input availability (WMS=1.03) which ranked sixth. This means that respondents were facing enormous constraints in the utilization of GAP technologies in the study area which could adversely affect quality of fruits and vegetables produced.

Table 3: Distribution of respondents according to the constraints experienced towards technologies in GAP

\begin{tabular}{llllll}
\hline Constraints* & Serious & Mild & $\begin{array}{l}\text { Not a } \\
\text { constraint }\end{array}$ & WMS & Rank \\
\hline $\begin{array}{l}\text { Poor understanding } \\
\text { of GAP }\end{array}$ & $105(38.9)$ & $138(51.1)$ & $27(10.0)$ & 1.29 & $5^{\text {th }}$ \\
$\begin{array}{l}\text { Farm input } \\
\text { availability }\end{array}$ & $69(25.6)$ & $141(52.2)$ & $60(22.2)$ & 1.03 & $6^{\text {th }}$ \\
$\begin{array}{l}\text { Training needed } \\
\begin{array}{l}\text { Lack of awareness } \\
\text { about technologies }\end{array}\end{array}$ & $168(62.2)$ & $99(36.7)$ & $3(1.1)$ & 1.61 & $3^{\text {rd }}$ \\
$\begin{array}{l}\text { Lack of credit } \\
\text { facilities }\end{array}$ & $225(82.3)$ & $117(43.3)$ & $12(4.4)$ & 1.48 & $4^{\text {th }}$ \\
$\begin{array}{l}\text { High cost of cropping } \\
\text { technologies }\end{array}$ & $246(91.1)$ & $15(5.6)$ & $9(3.3)$ & 1.81 & $2^{\text {nd }}$ \\
\hline
\end{tabular}

WMS = Weighted Mean Score

Source: Field Survey, 2019

* Multiple response

Pearson product correlation analysis of the relationship between selected socio-economic characteristics of the respondents and the utilization level of GAP technologies

Data presented in Table 4 shows that only one of the selected socio-economic characteristics was significant which was academic qualification of the respondents $\left(\mathrm{r}=0.541^{*}\right.$, $\mathrm{p}=0.022$ ) with the utilization level of technologies in GAP. This means that as respondents added more to their education qualification, there level of utilization of GAP technologies tends to increase. Respondents would have gathered more skills and knowledge during training at various education levels which may be beneficial in the utilization of GAP technologies. 


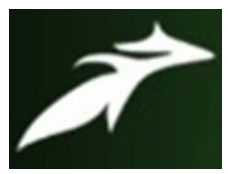

OYETORO John Oyewole et al, International Journal of Advances in Agricultural Science and Technology, Vol.8 Issue.1, January-2021, pg. 66-74

ISSN: 2348-1358

Impact Factor: 6.057

NAAS Rating: 3.77

Table 4: Pearson product correlation analysis of the relationship between selected socioeconomic characteristics of the respondents and the utilization level of GAP technologies

\begin{tabular}{llll}
\hline $\begin{array}{l}\text { Socio-Economic } \\
\text { Characteristics }\end{array}$ & $\begin{array}{l}\mathbf{r} \text { (correlation } \\
\text { coefficient) }\end{array}$ & P-value & Remark \\
\hline Age & -0.100 & 0.346 & Insignificant \\
Education qualification & $0.541 *$ & 0.022 & Significant \\
Household size & -0.105 & 0.325 & Insignificant \\
Annual income & 0.160 & 0.133 & Insignificant \\
\hline
\end{tabular}

Source: Field Survey, 2019

*Correlation is significant at the 0.05 level (2-tailed)

\section{Conclusion and Recommendations}

The study concluded that Fruit and vegetable farmers were aware and utilized the following GAP technologies: good cropping system, varieties that were pest and diseases resistant, and avoiding the use of used fertilizer bags for harvested vegetables and fruits while the constraints towards utilization of GAP technology were high cost of cropping technologies, lack of credit facilities, inadequate training and lack of awareness about technologies. Hence, the study recommended that government should subsidize inputs used by fruit and vegetable farmers to enable them explore GAP technologies for safe and nutritive food in the country. Also, adequate training on GAP technologies should be provided by extension agency.

\section{References}

[1]. Adedipe, N.O., Okuneye, P.A. and Ayinde, I.A. (2004). The relevance of local and indigenous knowledge for Nigerian agriculture. Paper presented at the International Conference on Bridging Scales and Epistemologies: Linking Local Knowledge with Global Science in Multi-scale Assessments. Alexandria, Egypt, 16-19 March 2004

[2]. Chowa, C., Garforth, C. and Cardey, S. (2013). Farmer Experience of Pluralistic Agricultural Extension, Malawi, Journal of Agricultural Education and Extension, 19:2, 147-166

[3]. FAO. (2010). "Towards the future we want, end hunger and make the transition to sustainable Agricultural and food systems". Rome. www.fao.org/docrep/015/an894e/an894e00.pdf

[4]. International Fund for Agricultural Development IFAD. (2013). Smallholders, food security and the environment: Rome, International Fund for Agricultural Development (IFAD). http://www.ifad.org/climate/resources/smallholders_report.pdf

[5]. Kalungu J.W, Filho, W. L. and Harris, D. (2013). Smallholder Farmers' Perception of the Impacts of Climate Change and Variability on Rain-fed Agricultural Practices in Semi-arid and Sub-humid Regions of Kenya, Journal of Environment and Earth Science, 3:7, 129-140.

[6]. Lefebvre, M., Espinosa, M., Paloma, S.G., Paracchini, M.L., Piorr, A. and Zasada, I. (2015). Agricultural landscapes as multi-scale public good and the role of the Common Agricultural Policy, Journal of Environmental Planning and Management, 58:12, 2088-2112

[7]. Lowder, S.K., Skoet, J. and Singh, S. (2014). What do we really know about the number and distribution of farms and family farms worldwide? Background paper for The State of Food and Agriculture 2014. ESA Working Paper No. 14-02. Rome, FAO. 


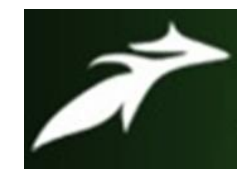

OYETORO John Oyewole et al, International Journal of Advances in Agricultural Science and Technology, Vol.8 Issue.1, January-2021, pg. 66-74

ISSN: 2348-1358

Impact Factor: 6.057

NAAS Rating: 3.77

[8]. Montagne, D., Cornu, S., Bourennane, H., Baize, D., Ratié, C. and King, D. (2007). Effect of Agricultural Practices on Trace Element Distribution in Soil, Communications in Soil Science and Plant Analysis, 38:3, 473491.

[9]. Onyekwelu, J.C; Olusola, J.A., Stimm, B., Mosandl, R. and Agbelade, A.D. (2015). Farm-level tree growth characteristics, fruit phenotypic variation and market potential assessment of three socio-economically important forest fruit tree species, Forests, Trees and Livelihoods, 24:1, 27-42.

[10]. Osebeyo, S.O. and Aye, G.C. (2014). Transaction costs and marketing decision: a case study of smallholder tomato farmers in Makurdi, Nigeria, Urban Planning and Transport Research, 2:1, 333-340,

[11].Osun State Government (2018): Agricultural sector. Available online https://osun.gov.ng/wpcontent/uploads/2018/11/agriculture-sector.pdf

[12]. Schneider M, Norman R, Steyn N, Bradshaw D. (2007): Estimating the burden of disease attributable to low fruit and vegetable intake in South Africa in 2000: South African Comparative Risk Assessment, South African Medical Journal, 97(8 Pt 2):717-723

[13].Slavin and Lloyd, (2012). Health Benefits of fruits and Vegetables, Advance Nutrition, 3(4):506-516. 